\title{
Classroom Management in DC Public School: Coolidge Senior High School
}

Muhammad Ari Saputra ${ }^{1}$

${ }^{1}$ Corresponding author, Sekolah Tinggi Agama Islam Negeri Mandailing Natal;

muhammadarisaputrar@stain-madina.ac.id

Received: February 18, $2021 \quad$ Accepted: July 28, $2021 \quad$ Published: July 29, 2021

\begin{abstract}
Teaching a language is a scientific process to give knowledge of language to the students in order that the students enable to communicate through in written and spoken form with one another. The students are able to communicate in spoken and written English accurately, fluently and in good manners. Managing a class of students is one of the biggest challenges faced by teachers. If teachers do not have an effective plan in place, there will not be much opportunity for students to engage in meaningful learning experiences. Thus, teachers will find themselves refereeing instead of teaching. Classroom management is a term used by teachers to describe the process of ensuring that classroom lessons run smoothly despite disruptive behavior by students. The goal of classroom management is to create and maintain a positive, productive learning environment, to support and foster a safe classroom community, to assist students to keep task focused, to reduce distraction from learning, to organize and facilitate the flow of learning activities and to help the students to manage them. The writer want to analysis the video taken from YouTube; focus on native or first language in English language teaching on senior high school level. The video coming to DC Public School: Coolidge Senior High School. This is descriptive and qualitative study. The data obtained through taken from youtube. After collecting the data, the author described and classified the data with following steps by the teacher. The finding of the study shows those are many steps while teaching and learning process in classroom management.
\end{abstract}

Keywords: English language teaching; Classroom management; Instructional design

To cite this article: Saputra, M.A.. (2021). Classroom management in DC public school: Coolidge Senior High School. SALEE: Study of Applied Linguistics and English Education, 2(02), 163 172. https://doi.org/10.35961/salee.v2i02.237 


\section{Introduction}

A teaching process is not only about how to transfer the knowledge, but also how to deliver it. Teachers as the main element in educational field are supposed to make the teaching and learning process can run well and make the students enjoy this lesson in order to achieve the planned teaching purposes and particularly to help students get good achievement. Language teachers should know and understand the concept of language teaching and learning. Learning a language and teaching a language are very different things; both teachers and students should be aware of the responsibilities that they bring to the process. Learning a language is a student-centered activity and it requires both motivation from the student and comprehensible language input from an outside source. Meanwhile, Brown (2000) gives explanation about the concept of language teaching and learning. Learning a language is acquiring or getting of knowledge of a subject or a skill by study, experience, or instruction and teaching a language is guiding and facilitating, enabling the learner, setting the conditions for learning a language. Language teaching and learning is a doing, thinking, and interpreting process that teachers and students interaction each other in a classroom.

Teaching a language is a scientific process to give knowledge of language to the students in order that the students enable to communicate through in written and spoken form with one another. There are good ways and bad ways to teach a language. Part of the teachers ${ }^{c e}$ responsibility is to update their skills as often as possible to reflect current ways of teaching and to have the most positive impact possible on the students. According to Brown stated that teaching is guiding and fasilitating learning, enabling the learner to learn, setting the condition for learning (Brown, 2000). Referring to the definitions above, the writer concludes that teaching a language is a scientific process done by teachers or teachers to transfer their language knowledge to students so that they are able to communicate to others. Learning a language is a process by students to get the language knowledge through interaction process in classroom.

Nowadays classroom management is one of important part when teaching and learning process, we know that the role of teachers in classroom is dominant, because concerns with the content of education or subject matter to be learned and concerns with the process of instruction, or how children learn, their attitudes towards learning, the resources and technology needed to support such learning and the context in which it occurs.

Managing a class full of students is one of the biggest challenges faced by teachers. If teachers do not have an effective plan in place, there will not be much opportunity for students to engage in meaningful learning experiences. Thus, teachers will find themselves refereeing instead of teaching. Research shows that a high incidence of classroom disciplinary problems has a significant impact on the effectiveness of teaching and learning. In this respect, it has been found that teachers facing such issues fail to plan and design appropriate instructional tasks. They also tend to neglect variety in lesson plans and rarely prompt students to discuss or evaluate the materials they are learning. According to Froyen stated that student's comprehension or seatwork's not monitored on a regular basis. In contrast, strong and consistent management and organizational skills have been identified as leading to fewer classroom discipline problems (Froyen, L. A., \& Iverson, 1999). It can be 
conclude that comprehension is the important part while managing classroom in teaching and learning process.

\section{Literature review}

\subsection{Classroom Management}

Classroom management is a term used by teachers to describe the process of ensuring that classroom lessons run smoothly despite disruptive behavior by students. The term also implies the prevention of disruptive behavior. According to Bellon stated that "The term 'classroom management' and 'discipline' are often used interchangeably" (Bellon, Bellon, \& Blank: 1992). However, too often the term 'discipline' focuses on misbehavior, ill deeds, and punishment and contains two significant limitations; first discipline highlight on individual rather than classroom, and second it connotes negative behavior only.

Whereas, classroom management is the term we will use to highlight all of those positive behaviors and decisions teachers make to facilitate the learning process of their students. It refers to all those activities necessary to create and maintain an orderly learning environment such as planning and preparation of materials, organization, decoration of the classroom and certainly the establishment and enforcement of routines and rules. In short, classroom management can be defined as: Classroom management is teachers' strategies that create and maintain an orderly learning environment and discipline means teachers' responses to student's misbehavior. Or also defined as: Classroom management is closely linked to issues of motivation, discipline and respect.

Many teachers establish rules and procedures at the beginning of the school year. They also try to be consistent in enforcing these rules and procedures. Many would also argue for positive consequences when rules are followed and negative consequences when rules are broken. There are newer perspectives on classroom management that attempt to be holistic. One example is affirmation teaching, which attempts to guide students toward success by helping them see how their effort pays off in the classroom. It relies upon creating an environment where students are successful as a result of their own efforts.

According to specialists in the field of education, "School and classroom management aims at encouraging and establishing student self-control through a process of promoting positive student achievement and behavior. Thus academic achievement, teacher efficacy, and teacher and student behavior are directly linked with the concept of school and classroom management." (Froyen, L. A., \& Iverson, A. M., 1999). Whereas according to Doyle, 1986 (as cited in Krause, Bouchner \& Duchesne, 2003), "Classroom management is certainly concerned with behavior, but it can also be defined more broadly as involving the planning, organization and control of learners, the learning process and the classroom environment to create and maintain an effective learning experience." (Krause, Bouchner \& Duchesne, 2003). The classroom environment not only provides a context for learning and includes the physical space, furnishings, resources and materials, but also the class atmosphere, participants 'attitudes and emotions, and the social dynamics of the learning experience.

A well-organized classroom is a classroom in which students know how to effectively make use of the classroom and its resources. Some of the teaching objectives focus on expected academic behaviors, appropriate use of materials and learning centers, and 
cooperation with peers. So, teacher should play a role to create a community of learners where students play an active part in forming their environment, understand their role students, and learn how to work effectively as an individual and with peers. All actions taken by the teacher should be focused on minimizing disruptions and fostering an environment where students can learn.

The goals of classroom management can be many, according to Asia University stated that there are two common goals of classroom management are to create and maintain a positive, productive learning environment and to support and foster a safe classroom community. The goals of classroom management are elaborated as below the first is to create and maintain a positive, productive learning environment; this goal is not meant for absolute control or to create an inert, docile, and totally compliant classroom and student body. Rather, an effective classroom management is to maintain students' interest, motivation and involvement. Thus, the focus is on activities that create positive, productive and facilitative learning environment.

The second is to support and foster a safe classroom community; another goal of classroom management is to support and foster a safe classroom community. It means that students are allowed to make the connections needed for learning to take place. Each student needs to feel comfortable enough to discuss their previous understanding without fear of being ridiculed for their misconceptions. In order to make the students comfortable enough to take these intellectual risks, it is necessary to set up the rules and routines which:

a. The rules and routines will give them a structure in which to interact with the teacher and each other.

b. The rules and routines need to be necessary, fair and specific if the students are to be expected to follow them.

c. Each rule or routine should come with a verbal or written description of why the rule is needed. If the rule is too vague on its own, examples should be given.

Classroom management strategy will not work if a teacher does not know his/her students. If the teacher takes the time to get to know the students, he or she can not only plan management issues better, but can also minimize disruptions in a more personal way. This has the added benefit of letting the students know that you care about them as people as well as students.

There are some of the aims of effective classroom management plan:

a. To assist students to keep task focus. Research demonstrates a significant relationship between the amount of content covered and student teaching (Berliner, 1988).

b. To reduce distraction from learning. This is an extension of the goal to keep student task focused.

c. To organize and facilitate the flow of learning activities. Assess to learning is assisted by the development of rules and routines that increase involvement and participation. Therefore, management goal must complement learning goal.

d. To help the students to manage themselves. That is, to assist students to take responsibility for their own actions as they impact their work within the classroom. (Tan, Parsons, Hinson, \& Sardo-Brown, 2003). 
The teacher should understand that children's behavior is not automatic. In fact, in many ways, the behavior we request of children as member of our classes could be contrary to their natural inclinations. In most classrooms, students' behavior is generally appropriate and does not present a challenge to the teacher. However, there are sometimes a few children whose behavior is at times inappropriate, nuisance and difficult to manage that teacher needs to seek additional help from experts, either to develop better strategies for coping with particular students or to find some other solutions.

Managing student's behavior is clearly a complex process. Teachers must be multi skilled, talented and able to deal with range of behavior. Different behavior management strategies were used in classroom. One of the strategies was corporal punishment. But, it was not allowed to be used or became the last resort in many countries all around the world. Therefore, corporal punishment has been replaced by alternative forms of discipline, which ranges from detention, extra written work, time out, removal of privileges, behavior contracts or agreements, in-school suspension and community service to exclusion and expulsion (Krause, Bochner, \& Duchesne, 2003).

As a process of appropriate teaching, classroom management needs to consider a student's development level. The goal of classroom management must reflect the everchanging needs of students of different level. There are four levels in the school context according to Brophy (2004), the first is Lower primary; the major focus during the early school years is on socializing the child to the role of student. Children at this level of development typically tend to follow adult authority. Thus, the emphasis is on teaching them what to do, more than on compliance with rules and regulation. The primary techniques would be establishing and introducing routines within the classroom. The second is Upper primary; by the time students reach this level, they are most likely familiar with school routines and generally able to maintain an appropriate learning environment.

The third is Secondary school; a testing of the routines appears during the middle school years. At this level, students' interest and control shift from adults to peers. The students may resist the teacher as authority. Classroom management needs to be developed that focus on compliance, rather than instruction. Getting the student to behave through rules and consequences will take more of centre stage in the classroom management plan. And the last is Post-secondary school; With the exception of serious problems, which require special attention and remediation, most of the students are mature and socialized to the school environment. Classroom management should take less energy and time, with the exception of setting the stage during the beginning of the year and perhaps refocusing students who may sway off course.

These processes of development are the general characteristics and individual students vary. As a pattern, however, we can see increasing independence and self-regulation as learners develop. Their affection for teachers decreases and they become more likely to question authority. This trend peaks in early adolescence, making classroom management at this age challenging. As stated by Eggen, \& Kauchack, during the high school years, students begin to behave like young adults and respond well to being treated as such. (Eggen, \& Kauchack, 2004). In short, students of all ages need the emotional security of knowing that their teachers are genuinely interested in them and sincerely care about their learning. 


\section{Methodology}

The research is qualitative in nature. Lichtman (2013: 7) explains that, in social sciences, qualitative research is about the analysis of phenomena, which is not based on counting. Merriam (2009: 14) gives four characteristics of qualitative research: "the focus is on process, understanding, and meaning; the researcher is the primary instrument of data collection and analysis; the process is inductive; and the product is richly descriptive." Furthermore, the information collected and analyzed, as stated by Saldaña (2011: 3) comprises textual materials such as documents or visual materials. The data of this research was video, the video taken from YouTube; focus on native or first language in English language teaching on senior high school level. The video coming to DC Public School: Coolidge Senior High School. The data obtained through taken from youtube. After collecting the data, the author described and classified the data with following steps by the teacher. The finding of the study shows those are many steps while teaching and learning process in classroom management.

\section{Finding and Discussion}

Learning at a classroom is the term used by teachers to describe the mechanism by which lessons are performed smoothly amid students' upsetting behaviour. Classroom management is the teacher's strategy, which creates an orderly learning environment and means teacher responses to misconduct. This part of the study is to analyze the YouTube video, focusing on English teaching in the first and secondary school languages. The video coming to DC Public School: Coolidge Senior High School with theme Develop higher-level understanding through effective questioning. The strategy use was developing higher-level understanding through effective questioning and the steps are:

a. Use a variety of questions

b. Ask higher-level questions at multiple levels of Bloom's taxonomy.

c. Students offer meaningful responses to high-level questions

d. Students pose higher-level questions to the teacher and each other

After viewing the video can be concluded in a management class. The first is sitting of this semicircular students indicated that the sitting position is set up properly so that all students well monitored by the teacher. The position is very fitting with the state of the student so that the student be active in class. The teacher becomes easier to teach with the sitting position, because all students will be well controlled.

We know that in teaching and learning process divided in to three steps, the first is PreActivity, the second is Main Activity and the last is Post Activity. After viewing the video there is opening the class handle by the teacher, the teacher said greeting to the students and said good morning. The core activities are the teacher showed the pictures or painting to the students and asks them to give opinion about the painting with different angle or opinion. Some of the students should give the opinion or comment based on the painting that is about feel, idea and so on. 
The teacher giving the poem, the students should provide the idea about that poem and comment to specific idea, the teacher ask to the students about students idea about that poem. After that the teacher give direction to makes a questions based on the text of poem it is related to the first steps of strategy use is use a variety of questions. And then all the students ask each other it is related to the other step is students offer meaningful responses to highlevel questions. All the students have interesting because management the class is very attractive.

According to Gurney (2007: 88) stated that the most significant in teaching and efforts to be an effective teacher is the creation of an effective learning environment, that it is the interaction of the following five key factors that provide a foundation for a good teaching. There are five factors for effective teaching:

a. Teacher knowledge, enthusiasm and responsibility for learning.

b. Classroom activities that encourage learning.

c. Assessment activities that encourage learning through experience.

d. Effective feedback that establishes the learning processes in the classroom.

e. Effective interaction between the teacher and the students, creating an environment that respects, encourages and stimulates learning through experience.

We focus on classroom management that is many classrooms this is the key factor that supports an effective learning environment. The highlight the need for the classroom environment to be a place that allows students to learn. That may be a very obvious statement but in considering the average class of senior students, many factors would in fact mitigate against a good learning environment being created and not through lack of trying or experience on behalf of the teacher. The fact that a teacher may be successful in one year does not necessarily mean that success will be continued in the next year. The teaching environment may be the same but the attitudes that each cohort brings to a classroom will always influence the outcome. A teacher must be able to identify the ebbs and flows of each class and work with the students to create the learning environment. Teachers need to be prepared to test what is going on in the class, for example, through feedback questionnaires on what they doing.

In reflecting on this feedback and on the classroom activity of a year, a teacher could identify specific exercises and techniques that engaged the students. It takes patience and persistence to have the classes work cooperatively, to carry out independent research, and to report back to small groups and to the whole class - the goal is that through the teacher's endeavors, the learning will become the student's own learning. The activities need to be part of their learning regime and not something that is imposed. This is an area that requires planning, reflection and preparation. This is clearly a central issue in this aspect of the learning environment: it is a very self-conscious action on the part of the teacher. The activities that are used in the class to engage the students must be reviewed, revisited and refocused so that they are constantly drawing the students into an effective interaction with the subject. Effective Teaching is not a passive action.

In order to be successful in teaching, teachers need to have a planning for effective classroom management. There are six suggested planning for teachers to effectively manage 
a classroom. The planning include reflect student development needs, creating a physical environment, creating a learning environment, creating, teaching and maintaining rules and procedures, managing the classroom activities, getting students to cooperate and classroom management style. The descriptions for the planning are explained below.

a. Reflecting students' development needs: Students' characteristic.

b. Creating a learning environment.

c. Creating a physical environment.

d. Creating, teaching and maintaining rules and procedures.

e. Effectively managing classroom activities.

f. Getting students to cooperate.

g. Classroom management style.

Based on that planning above, we can elaborate that classroom management is one of the most important roles played by teachers because it determines teaching success. Effective teachers appear to be effective with students of all achievement levels regardless of the levels of heterogeneity in their classes. Effective classroom managers are those who understand and use specific techniques. Even if the school they work in is highly ineffective, individual teachers can produce powerful gains in student learning.

Effective use of classroom management techniques can dramatically decrease the disruptions in your classes. Students in classes where effective management techniques are employed have achievement higher than students in classes where effective management techniques are not employed. It is not possible for a teacher to conduct instruction or for students to work productively if they have no guidelines for how to behave or when to move about the room, or if they frequently interrupt teacher and one another. Students in the class where rules and procedures were implemented might have been less disruptive by their very nature than students in the class that did not implement rules and procedures.

Effective classroom management needs good rules and procedures. Rules and procedures vary from one teacher to another and from one classroom to another. The most effective classroom management involves the design and implementation of classroom rules and procedures. Rules and procedures should not simply be imposed on students. The proper design of rules and procedures involves explanation and group input. Explanation is important in helping the students to see the need for the rule therefore to accept it.

The most effective classroom managers don't simply impose rules and procedures on students. Rather, they engage students in the design of the rules and procedures. A group discussion will produce a compromise rule or procedure that all can live with. If not, you, the teacher, should have the final word in the deliberations. Well-articulated rules and procedures that are negotiated with students are a critical aspect of classroom management, affecting not only the behavior of students but also their academic achievement.

The Important to the success of two of the other aspects of effective classroom management rules and procedures, and disciplinary interventions. It is important to communicate appropriate levels of dominance and to let students know that you are in control of the class and are willing to lead. It is also important to communicate to convey the message that you are interested in the concerns of the students and individuals and the class as a whole.

Students with good relationship with the teacher accept more readily the rules and procedures and the disciplinary actions that follow their violations. Teachers should be 
effective instructors and lecturers, as well as friendly, helpful, and congenial. They should be able to empathize with students, understand their world, and listen to them. The nature of an effective teacher-student relationship is one that addresses the needs of different types of students. Finally, the result that video is the classroom management running well, all the students giving attention when teaching and learning process and become active in classroom.

\section{Conclusion}

Classroom means provides a learning context and includes the physical environment, equipment, resources and materials as well as the school atmosphere, the attitudes and emotions of the participants and the social dynamics of the experience. Classroom management means ensuring that classroom courses are conducted smoothly despite student disruption; closely linked to motivation, discipline and respect. The strategy use was developing higher-level understanding through effective questioning. The steps were; Use a variety of questions, Ask higher-level questions at multiple levels of Bloom's taxonomy, Students offer meaningful responses to high-level questions, Students pose higher-level questions to the teacher and each other. Managing a classroom is not an easy task. Teacher needs to consider several things such as the child's development level, the learning and physical environment, rules and procedure, classroom activities, student's cooperation and classroom management style.

\section{References}

Bellon, J.J., Bellon, E.C., \& Blank, M.A. at al. (1992). Teaching from a research knowledge base: A development and renewal process. New York: Macmillan Publishing Company.

Brown, D. H. (2000). Principles of language learning \& teaching. (4th ed.). New York: Longman.

Brophy, J., (2004), Motivating Students to Learning, Lawrence Erlbaum Associates,. New Jersey.

Froyen, L. A., \& Iverson, A. M. (1999). School wide and classroom management: The reflective educator-leader (3rd ed.). Upper Saddle River, NJ: Prentice-Hall.

Gage, N.L. \& David C. Berliner.(1988). Educational Psychology. Boston: Houton. Mifflin Company

Gurney, Philip. (2007). Five Factors for Effective Teaching. New Zealand Journal of Teachers' Work, Volume 4, Issue 2, 89-98, 2007

Johnson, P Doyle. 1986. Teori Sosiologi Klasik dan Modern. Jakarta : Gramedia Pustaka Utama

Krause, K. L., Bochner, S., \& Duchesne, S. (2003). Educational psychology for learning and teaching. Australia:Thomson. 
Lichtman, Marilyn. (2013). Qualitative Research in Education : A User's Guide. (Third Edition). Los Angeles : Sage Publications, Inc.

Merriam, Sharran B. (2009). Qualitative Research: A Guide to Design and Implementation. San Fransisco: John Wiley \& Sons, Inc.

Richards, Jack C., and Theodore Rodgers (2001). Approaches and Method in Language Teaching. Second Edition. New York: Cambridge University Press.

Saldaña, Johnny. (2011). Fundamentals of Qualitative Research: Understanding Qualitative Research.New York: Oxford University Press.

Santrock, J.W. (2006). Educational psychology: Classroom update: Preparing for PRAXIS TM and practice. 2nd ed. New York:Mc Graw Hill.

Tan O.S., Parsons, R.D., Hinson, S.L., \& Sardo-Brown, D. (2003). Educational psychology: A practitioner-researcher approach. Australia: Thomson. 